\title{
Perception and adaptation models of climate change by the rural people of lake Tana Sub-Basin, Ethiopia
}

\author{
Solomon Addisu*, Getachew Fissha', Birhanu Gediff' and Yemane Asmelash²
}

\begin{abstract}
Background: Agriculture is the most susceptible sector to climate change related hazards. Unusual temperature and rainfall occurrence in terms of amount and distribution usually lead to poor harvest and/or complete crop failure and shortage of pasture and animal feed in Ethiopia. Such extreme conditions ultimately result in drought with a resultant depletion of assets, societal vulnerability, mass migration and loss of life. This research work has been conducted to fill such knowledge gaps of the target population in Lake Tana Sub-Basin. The objectives of the research were to assess the perception of the rural people about climate change and adaptation models. To attain this research objective, both primary and secondary data from different sources were collected. The collected data statistical analyses were done by STATA version 11 computer program.

Results: Results of Heckman probit and multinomial logistic regression models revealed that age, educational level, wealth status, agricultural extension services, and distance to the nearest health center are found to be significant for determining climate change adaptation. The farmers 'perceptions to climate change found to be statistically significant related to those factors such as: marital status, farm size, climate change information access and the level of income generations. The majority of the respondents argued that the strategies and programs of climate change adaptations need further enforcement to implement it fully up to the level of expectations.
\end{abstract}

Conclusion: It is therefore recommended that the legislative bodies and development planners should design strategies and plans by taking into account impacts of declining summer rainfall and increasing temperature on rural livelihoods. Moreover, adverse impacts of climate change and adaptation strategies should be a crosscutting issue.

Keywords: Climate change perception, Adaptation, Heckman probit model, Multinomial logistic regression model

\section{Background}

The intensity, frequency and the effects of drought in Ethiopia and the number of people in need of food aid have increased since the mid-1970s. Reports indicate global climate change to be the cause of such dramatic increase in the intensity and frequency of drought. El Nińo-Southern Oscillation (ENSO) episodes are reported to be the main cause of drought in Ethiopia because of its effect on the rain producing weather systems over Ethiopia (Country report 2010).

\footnotetext{
*Correspondence: soladd2000@yahoo.com

${ }^{1}$ Department of Natural Resources Management, College of Agriculture and Environmental Sciences, Bahir Dar University, Bahir Dar, Ethiopia Full list of author information is available at the end of the article
}

The high vulnerability of people in Africa to climate variability and or change is attributed largely to their low adaptive capacity, which results from deteriorating, extensive poverty, ecological resources, unequal land distribution and high dependency on the natural resource base. Improving adaptive capacity is important in order to reduce vulnerability to climate change (Elasha et al. 2006). The third assessment report by IPCC (2001) foresees a temperature rise in the range of $2-6^{\circ} \mathrm{C}$ by 2100 . Temperature increases in the Millennium Ecosystem Assessment scenarios are in the lower range of $1.5-2.0^{\circ} \mathrm{C}$ above pre-industrial revolution temperatures in 2050 , and $2.0-3.5^{\circ} \mathrm{C}$ higher in 2100 . Such temperature increases might lead to reductions in crop yield.

\section{Springer}


The combined effect of temperature rises and carbon dioxide enhancement varies among crops (Robinson et al. 2012).

Despite the low adaptive capacity of Africa in general and Ethiopia in particular, people have developed traditional adaptation strategies to face the great climate inter-annual variability and extreme events. They have been trying, testing, and adopting different types of coping strategies (Elasha et al. 2006). An unusually persistent drought may increase people's vulnerability in the short term; but, it may encourage adaptation in the medium to long term. This reinforces the observation that local people have perceived, interacted with, and made use of their environment with its meager natural resources and changing climatic conditions. This practical coping mechanism is particularly true for the drought prone areas in Ethiopia and in the African Sahel region, which is susceptible to frequent climatic hazards (Elasha et al. 2006).

According to Elasha et al. (2006), the most common climate variability and climate change adaptation strategies in rural Ethiopia are:

- Diversification of herds and incomes,

- Growing of drought and heat resistant and early maturing crop varieties,

- Use of small-scale irrigation, water harvesting and storage,

- Improved water exploitation methods,

- Labor migration, response farming,

- Increased agro-forestry practices,

- Changes in farm location,

- Reduction in herd and farm sizes, and food storage,

- Crop and animal diversification,

- Controlled grazing,

- Selling of assets,

- Herd supplementation,

- Communal holding of grazing lands, and

- Indigenous early warning and forecasting systems.

Ethiopian poverty reduction strategy document also clearly stated the impacts of climate variability recognized that agriculture is very vulnerable to the variation. It has set Industrialization Led Agricultural Development as a key to poverty reduction. However, the subject of climate change has not been treated in any of the agricultural sectors directly or indirectly. The document clearly states that Economic development through agriculture to be fundamental to the use of available water, land and improved inputs. Capacity building through training of farmers and the development of human capacity through training at the middle level is among the key areas of focus (Elasha et al. 2006).

\section{Methods}

Ethiopia is located in Northeastern or East Central Horn of Africa lying between 3-15 degrees north latitude, 33-48 degrees east longitude (Fig. 1). Ethiopia is bordered in the east Somalia and Djibouti, in the south by Kenya, in the northeast by Eritrea and in the west by the North and South Sudan. The country has a total area of about 1.1 million $\mathrm{km}^{2}$ and comprises of 12 river basins with varying size and water resource potential (CSA Central Statistical Agency 2007). Blue Nile Basin (Locally called the Abay Basin), the largest river basin in Ethiopia, is one of those basins which consist of Lake Tana Sub-basin. Lake Tana is the largest freshwater and oligotrophic-high altitude lake in the world (CSA Central Statistical Agency 2007).

This study was conducted in LTSB which is designated as one of the development corridors in the country and huge investments are being incurred to promote large scale farmer managed irrigation and also to generate hydroelectric power. It is found in the Amhara National Regional State (ANRS) and is situated within the upper reaches of the Blue Nile River. It is located within latitudinal and longitudinal ranges between $10^{\circ} 58 \mathrm{~N}-12^{\circ} 47 \mathrm{~N}$ and $36^{\circ} 45 \mathrm{E}-38^{\circ} 14 \mathrm{E}$, respectively. It covers a total area of $1,589,654.98$ ha.

As climate change affects the socioeconomic condition of a given area, a socioeconomic survey was conducted at the household level of the Lake Tana Sub-Basin. The sample households from the upper and the lower sub-basin were selected. Then structured questionnaires which consist of both open and close-ended questions were prepared, pre-tested and administered. To substantiate the result, interviews and focus group discussions (FDG) were prepared and conducted. Moreover, secondary data such as crop, livestock, population, etc. were collected from the districts agricultural bureaus.

The number of sample households selected was determined by following Cochran (1977) formula. Based on this, 300 household heads were selected from the upper and lower LTSB. These sampling household heads were proportionally allocated in each of the 15 kebeles (the smallest administrative unit). At each of the 15 kebeles, sample households were chosen using simple random sampling techniques from the list of households (Table 1). Data recorders were appointed who went to each household and fill the format by asking respondents orally. If the household heads could not be available during the time of data collection, the wife would be taken as the information source.

The total number of administrative kebeles in each subbasin was counted. The sub-basin was subdivided based on the climate hazard exposure namely flood for the lower sub-basin (LSB) and drought for the upper sub-basin 


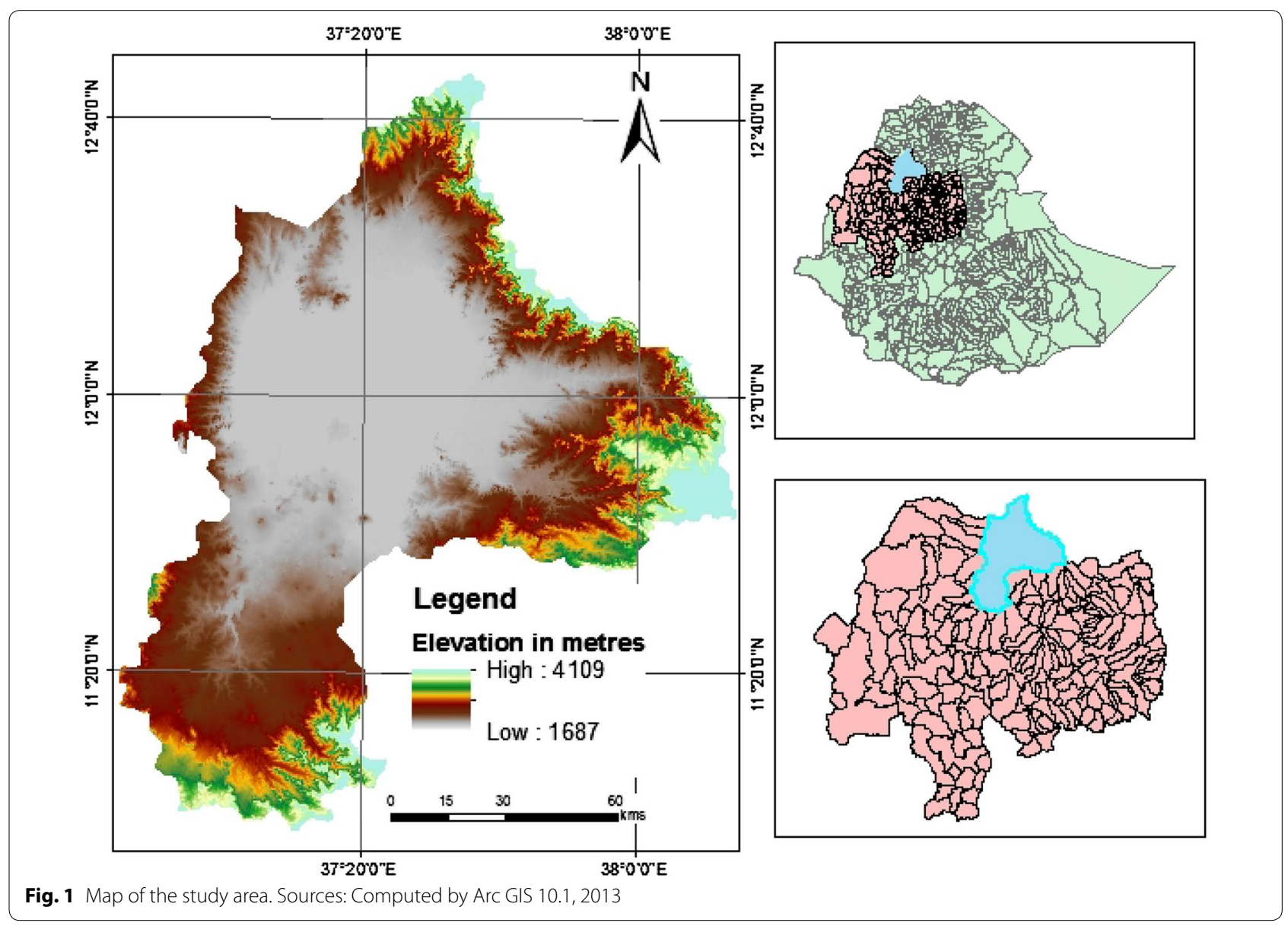

Table 1 Sample kebeles of the study area

\begin{tabular}{llllll}
\hline $\begin{array}{l}\text { LSB } \\
\text { kebele }\end{array}$ & $\begin{array}{l}\text { No. } \\
\text { HHs }\end{array}$ & District & $\begin{array}{l}\text { USB } \\
\text { Kebele }\end{array}$ & $\begin{array}{l}\text { No. } \\
\text { HHs }\end{array}$ & District \\
\hline Shaga & 1525 & Fogera & Michaeldebir & 2071 & Libokemkem \\
Shina & 2196 & Fogera & Libo & 1930 & Libokemkem \\
Kuharmichael & 1241 & Fogera & Mokesh & 1509 & Farta \\
Bebekis & 1588 & Fogera & Amjaye & 1405 & Farta \\
Tezamba & 1202 & Libokemkem & Gentegna & 1302 & Farta \\
Bira & 1406 & Libokemkem & Sores & 1100 & Farta \\
Shina tsion & 1402 & Libokemkem & Darmo & 1377 & Farta \\
Kab & 1538 & Libokemkem & & & \\
\hline
\end{tabular}

Source District administrative office, 2014

(USB). This was done based on the local knowledge and ground truth exercise with local administration and the community leader during the reconnaissance survey. Areas that have less than $2 \%$ slope and below 1825 m.a.l were delineated as flood plain areas. This was finally recalculated by employing flood zoning analysis technique, which uses the weighted sum overlay of slope, elevation, drainage density, land use/land cover and soil types.
Selection of sample households was done on the selected administrative kebeles from each agro-ecology sub-basins. Independent samples of households were calculated from a sample frame (number of households in each sub-basin). Sample size calculation for selection of households from each sub-basin considers: (i) the proportion (p) for the different variables of investigation $(\mathrm{p}=0.5)$; (ii) design effect of two to make an adjustment for non-random effect; (iii) $10 \%$ margin of error at $95 \%$ confidence; and (iv) $5 \%$ non-response rate (Cochran 1977). The formula used to calculate sample size is given as:

$$
\begin{aligned}
& n o i=\frac{d(z x / 2)^{2} * p(1-p)}{\varepsilon^{2}} \\
& n i=\frac{n o i}{1(n o i-1) \frac{1}{N i}}
\end{aligned}
$$

where $\mathrm{Ni}=$ the total number of households in each subbasin ( $\mathrm{i}=1,2,3) ; \mathrm{n}_{0 \mathrm{i}}=$ non-adjusted sample size for each sub-basin $n_{i}=$ adjusted sample size for each for each sub-basin; $z^{x} / 2^{2}=$ value of normal distribution at $95 \%$ 
confidence $(\mathrm{z}=1.96) ; \mathrm{P}=$ the proportion for the key variables to be investigated ( $\mathrm{p}=0.5) ; \varepsilon=$ margin of error $(10 \%)$; and $d=$ design effect.

Based on the above formula, 276 sample households were the minimum sample size required for the study. The proposed and actual sample size for the household survey is given in Table 2.

\section{Analytical framework Heckman probit and multinomial logistic regression model}

The selection of whether or not to use any adaptation option could fall under the general framework of its value and production improvement capacity. Assume a rational farmer who pursues to improve agricultural productions over a specific time and must choose among a set of ' $\mathrm{j}$ ' adaptation options. Hence, the farmer ' $i$ ' decides to use ' $j$ ' adaptation options if the perceived benefit from option ' $j$ ' is greater than the utility from other options (say, k) stated as:

$$
U_{i j}\left(\beta_{j}^{\prime} X_{i}+\varepsilon_{j}\right)>U_{i k}\left(\beta_{k}^{\prime} X_{i}+\varepsilon_{k}\right), k \neq j,
$$

where $U i j$ and $U i k$ are the perceived value by farmer $\mathrm{i}$ of adaptation options $\mathrm{j}$ and $\mathrm{k}$, respectively; $\mathrm{X} i$ is a vector of explanatory variables that influence the choice of the adaptation option: $\beta j$ and $\beta k$ are parameters to be estimated and $\varepsilon j$ and $\varepsilon k$ are the error terms. Under the revealed preference assumptions that the farmer practices an adaptation option that generates net benefits and doesn't practice an adaptation option otherwise, we can relate the observable sub-basin choice of practices to the unobservable continuous net gain variable as $Y i j=1$ if $\mathrm{U} i j>0$ and $\mathrm{Y} i j=0$ if $\mathrm{U} i j<0$. In this formation, $\mathrm{Y}$ is a dichotomous dependent variable taking the value of 1 when the farmer chooses an adaptation option in question and 0 otherwise. The probability that farmer ' $i$ ' will choose adaptation option ' $j$ ' among the set of adaptation options could be defined as:

$$
\begin{aligned}
P\left(\frac{Y-1}{X}\right) & =P\left(\frac{U_{i j}>U_{i k}}{X}\right) \\
& =P\left(\beta_{j}^{\prime} X_{i}+\varepsilon_{j}-\beta_{k}^{\prime} X_{i}-\varepsilon_{k}>0 / X\right) \\
& =\left(\left(\beta_{j}^{\prime}-\beta_{k}^{\prime}\right) X_{i}+\varepsilon_{j}-\varepsilon_{k}>0 / X\right) \\
& =P\left(\beta * X_{i}+\varepsilon *>0 / X\right)=F\left(\beta * X_{i}\right),
\end{aligned}
$$

where $\varepsilon^{*}=$ a random disturbance term, $\beta^{*}=$ a vector of unknown parameters that can be interpreted as the net influence of the vector of explanatory variables influencing adaptation, and $\mathrm{F}\left(\beta^{*} \mathrm{X} i\right)=$ the cumulative distribution of $\varepsilon^{*}$ evaluated at $\beta * X i$.

Depending on the assumed distribution that the random term follows several qualitative choices, models such as linear probability, logit/probit, model could be estimated (Glwadys 2009). In LTSB, we assumed that several adaptation choices and the appropriate economic model would be either a multinomial logit/ probit $(\mathrm{MNL} / \mathrm{p})$ regression model. Both models estimate the effect of explanatory variables on a dependent variable involving multiple choices with unordered response categories (Glwadys 2009). The MNL specification was adopted to model climate change adaptation behavior of farmers involving in a sub-basin or agro-ecology dependent variables with multiple choices. Thus, the probability that household ' $i$ ' with characteristics ' $X$ ' choose adaptation option ' $j$ ' was specified as:

$$
\begin{aligned}
P_{i j} & =\operatorname{prob}(Y=1) \\
& =\frac{\ell^{X^{\prime \beta}}}{1+\sum_{j=1}^{j} \ell^{X^{\prime} \beta}}, \quad j=1 \ldots i
\end{aligned}
$$

where $\beta$ is a vector of parameters that satisfy $\ln (\mathrm{Pij} /$ Pik) $=X^{\prime}(\beta j-\beta k)$ (Glwadys 2009). Undesirable and consistent parameter estimates of the MNL model require the assumption of independences of irrelevant alternatives (IIA) to hold. The validity of the IIA assumption could be tested using Hausman's specification test which is based on the fact that if a choice set is immaterial, removing a choice or choice sets from the model altogether will not change parameter estimates systematically. Differentiating the above equation with respect to each explanatory variable provides marginal effects of the explanatory variables given as:

$$
\frac{\partial P_{j}}{\partial X_{k}}=P_{j}\left(\beta_{j k}-\sum_{j=1}^{j-1} P_{j} \beta_{j k}\right)
$$

Table 2 The proposed and actual sample size of households

\begin{tabular}{lllll}
\hline Sub-basins & $\begin{array}{l}\text { Number of HHs in each } \\
\text { sub-basin }\end{array}$ & $\begin{array}{l}\text { Adjusted } \\
\text { sample size }\end{array}$ & $\begin{array}{l}\text { Non-response } \\
\text { rate }\end{array}$ & $\begin{array}{l}\text { Actual sample } \\
\text { size } \\
\text { sample size }\end{array}$ \\
\hline Lower sub-basins & 12,098 & 136 & 5 & 141 \\
Upper Sub-basins & 10,694 & 134 & 5 & 139 \\
Total & 22,792 & 270 & 10 & 150 \\
\hline
\end{tabular}

Source Interpolation and household survey (2014) 
Using the MNL model for this research analysis gives rise to a sample selectivity problem because only those who perceive climate change will adapt the adverse impacts of climate change. Certainly, adaptation to climate change begins with two processes as: perceiving change, and then decide on a particular adaptation choice. Therefore, Both the Heckman sample selectivity probit model and MNL model have been used to study the determinants of climate change (Glwadys 2009).

The analysis was based on cross-sectional data collected from the rural households of LTSB. Before initial runs of the model, the data were checked for the presence of any multi co-linearity in the data set. Based on the discussions of the experienced local residents and scientific researches in LTSB adaptation studies, a range of household and farm characteristics, institutional factors, and other factors that describe local conditions were hypothesized to influence farmers' adaptation choice in the study area. Choices of variables and hypothesis to be tested in the adaptation model include variables such as:

- use of climate change resilient variety

- forage stock,

- crop diversity,

- crop intensity,

- change planting date,

- irrigation,

- water harvesting,

- soil and water conservation,

- fertilizer use and others

Those who respond no adaptation methods were considered in the model analysis. Generally, the household characteristics considered to have differential impacts on adaptation decisions. Age, educational level, household size, marital status, women's participation in social affairs and wealth status were taken in the analysis as common household characteristics in both USB and LSB. According to Teklewold et al. (2006), older farmers, in the range of productive age group, positively influence climate change adaptation and perception of their farm experiences. It could also be that older farmers have more experience in farming and are better able to assess the characteristics of modern technology than younger farmers, and hence a higher probability of adopting the practice.

Higher level of education is often hypothesized to increase the probability of adopting new technologies (Daberkow and McBride 2003). Indeed, education is expected to increase one's ability to receive, decode, and understand information relevant to make innovative decisions. Sex of the household head is also hypothesized to influence the decision to adapt changes based on the changing climate situations. Based on the discussions held in both USB and LSB, the rural women in LTSB have taken more responsibility to manage the source of energy and house management more than men and hypothesized as more vulnerable to climate change. Household size as a proxy to labor availability may influence positively as its availability reduces the labor constraints (Teklewold et al. 2006). However, according to Tizale (2007), there is a possibility that households with many family members may be negatively respond unless it is forced to divert part of the labor force to off-farm activities. Wealth is believed to reflect past achievements of households and their ability to bear risks. Thus, households with higher income and greater assets are in better position to adapt climate change (Shiferaw and Holden 1998).

Of the many sources of information available to farmers, agricultural extension is the most important for analyzing the adaptation strategy implementation. It is hypothesized that access to extension services is positively related to climate change adaptation, in the specific case of climate change adaptation, access to climate information may increase the likelihood of uptake of adaptation techniques. The occupation of the farmer in LTSB is an indication of the total amount of time available for farming activities. Hence, off-farm employment might be positive for larger family size and negative for smaller family size based on the availability of labor. Similarly, farm size can contribute to adapting an argument that has justified numerous efforts to reduce tenure insecurity (Tizale 2007).

Other factors, like local climatic conditions and agroecological conditions were expected to influence the adaptation nature of the LTSB households. Dummy variables for provinces to take into account any specific institutional arrangements having bearing on the ability of their farmers to adapt to climate change were also important. The farm characteristics hypothesized to influence adaptation in this study were farm size (large scale or small-scale) and land resources management. Moreover, income from off-farm and sale of surplus products were expected to increase the adaptive capacity of the rural people in LTSB. The variables hypothesized to determine adaptation behavior, a brief description of each variable, its value, and expected sign in relation to climate change adaptation are stated in Table 3.

\section{Results and discusions}

In this section, two models [the Heckman probit and the multinomial logit (MNL) model] for adaptation choices to climate change in the LTSB were estimated by using the statistical software STATA version 11.0: the Heckman probit and the multinomial logit (MNL) model. 
Table 3 Variable hypothesized to affect adaptation decision by farmers in the LTSB

\begin{tabular}{|c|c|c|c|}
\hline Variable & Description & Value & Expected sign \\
\hline \multicolumn{4}{|l|}{ Household characteristics } \\
\hline Age & Age of the head of the farm household & $1=<35$ and $0=>35$ & Cannot be signed \\
\hline Education & Educational level of the $\mathrm{HHs}$ & $1=$ illiterate, $0=$ literate & Positive \\
\hline Sex & Sex of the head of the farm $\mathrm{HH}$ & $1=$ female, $0=$ male & Positive/negative \\
\hline Household size & Number of family members of a $\mathrm{HH}$ & Number & Positive/negative \\
\hline Marital status & Marital status of head of the $\mathrm{HH}$ & $1=$ married, $0=$ unmarried & Positive/negative \\
\hline Wealth status & $\begin{array}{l}\text { An index was constructed using } \\
\text { household ownership }\end{array}$ & $\begin{array}{l}1=\text { rich and medium, } 0=\text { poor } \\
\text { and better off }\end{array}$ & Positive/negative \\
\hline Women participation & Participation of women in social affairs & $1=$ yes, $0=$ no & Positive \\
\hline \multicolumn{4}{|l|}{ Farm characteristics } \\
\hline Farm size & Land holding size of the $\mathrm{HH}$ & Number & Positive \\
\hline Land shared in & Land holding size shared in by the $\mathrm{HH}$ & Number & Positive \\
\hline Land shared out & Land holding size shared out by theHH & Number & Positive \\
\hline \multicolumn{4}{|l|}{ Institutional characteristics } \\
\hline Climate information & If household gets information about climate & $1=$ yes, $0=$ no & Positive \\
\hline Extension & If household has access to extension services & $1=$ yes, $0=$ no & Positive \\
\hline Off-farm employment & Income from off-farm activities during the survey year & $1=$ yes, $0=$ no & Positive/negative \\
\hline \multicolumn{4}{|l|}{ Others } \\
\hline Agro-ecology & Agro-ecology of the household head & $1=U S B, 0=L S B$ & Positive/negative \\
\hline $\begin{array}{l}\text { Distance market and health } \\
\text { center }\end{array}$ & $\begin{array}{l}\text { Distance from the } \mathrm{HH} \text { to the nearest market place in } \\
\text { KM }\end{array}$ & Number & Positive \\
\hline Means of transport & $\begin{array}{l}\text { Means of transport from the } \mathrm{HH} \text { to the } \\
\text { nearest market place }\end{array}$ & $1=$ on foot, $0=$ vehicles & Positive \\
\hline Off-farm income & Income from non-farm/off-farm activities & Number & Positive \\
\hline Income from crop sale & Income from selling surplus products & Number & Positive \\
\hline
\end{tabular}

Source: own reconnaissance survey, 2013

The analysis was based on cross-sectional data collected from the rural households of LTSB. Before initial runs of the model, the data were checked for the presence of any multicollinearity in the data set. Among the variables hypothesized to influence adaptation in the above section, these correlation coefficients which do not suggest the incidence of strong co-linearity were dropped from the model. The correlation matrix table indicates that the relationship of factor variables show that it is free from the multicollinearity problem (Table 4).

This sub-topic presents the results of the Heckman probit adaptation model. The model determines the likelihood of perceiving any change in the climate as well as the likelihood of farmers' adapting to these changes. The dependent variable in the selection equation is binary indicating whether or not a farmer perceives climate change; the dependent variable in the outcome equation is also binary indicating whether or not a farmer responded to the perceived changes by adapting farming practices. The likelihood function for the Heckman probit model was significant (Wald $\chi^{2}=46.99$ with $\mathrm{P}<0.0000$ ), showing a strong explanatory power.
As shown in Table 5 below, the likelihood of taking adaptation practice found to be statistically significant for the factor variable of the sex of the household head at the $1 \%$ level of significance. The likelihood of taking adaptation practice decreases by $58.84 \%$ as the household becomes female headed as compared to the male headed households. It implies that in LTSB households, female headed households are more vulnerable to the adverse impacts of climate change since most of the responsibilities in managing the house as well as the field work were handled by the head of the household. In the rural parts of LTSB, the socioeconomic inequality of female headed households created more burdens on the female households than the male headed households. Therefore, the participation of women in the socioeconomic activities of the LTSB played a significant role in the adaptation of climate change impacts on their livelihoods.

As it was hypothesized in the above section, educational level, wealth status, off-farm employment, agricultural extension services and the distance to the nearest health center of the household head is found to be statistically significant at $10 \%$ level of significance. 
Table 4 Correlation matrix of the independent variables Multicollinearity

\begin{tabular}{|c|c|c|c|c|c|c|c|c|}
\hline Variable & Age & Sex & Agro-ecology & Education & Marital status & HH size & Wealth status & Farm size \\
\hline Age & 1.0000 & & & & & & & \\
\hline Sex & 0.0024 & 1.0000 & & & & & & \\
\hline Agro-ecology & -0.1737 & 0.0413 & 1.0000 & & & & & \\
\hline Education & -0.0715 & -0.0227 & 0.0245 & 1.0000 & & & & \\
\hline Marital status & -0.0484 & -0.4693 & -0.1102 & 0.0148 & 1.0000 & & & \\
\hline HH size & -0.0823 & -0.1396 & -0.1290 & 0.0458 & 0.1964 & 1.0000 & & \\
\hline Wealth status & 0.0721 & -0.0622 & -0.5369 & 0.0176 & 0.1401 & 0.0874 & 1.0000 & \\
\hline Variable & Extension & Off-farm & Info. & Women & Dist. w & Dis.to H & Income & Farm size \\
\hline Farm size & -0.1204 & -0.0722 & -0.1641 & -0.1011 & 0.1916 & 0.1700 & 0.3107 & 1.0000 \\
\hline Extension & 0.0343 & 0.0367 & -0.0629 & -0.0131 & 0.0156 & -0.0022 & 0.0631 & 0.0578 \\
\hline Off-farm & -0.0140 & 0.0825 & -0.0097 & 0.0676 & -0.0375 & 0.0087 & 0.0734 & -0.0376 \\
\hline Information & -0.0132 & 0.0496 & 0.0367 & -0.0322 & 0.0345 & -0.0432 & -0.0009 & -0.0818 \\
\hline Woman's role & 0.0008 & -0.0715 & -0.0356 & -0.0238 & 0.0572 & 0.0508 & 0.0076 & 0.0040 \\
\hline Distance $\mathrm{W}^{\mathrm{b}}$ & -0.0743 & 0.1015 & 0.0072 & -0.0217 & -0.0870 & -0.0199 & -0.0406 & -0.0006 \\
\hline Distance $\mathrm{HC}^{\mathrm{a}}$ & -0.0802 & 0.0196 & 0.1411 & 0.0309 & -0.0401 & 0.0487 & -0.1739 & -0.0017 \\
\hline Income & -0.0761 & 0.0095 & 0.1030 & 0.0394 & 0.0408 & -0.0062 & -0.1313 & 0.0579 \\
\hline \multicolumn{9}{|l|}{ Farm size } \\
\hline Extension & 1.0000 & & & & & & & \\
\hline Off-farm & 0.0176 & 1.0000 & & & & & & \\
\hline Information & -0.0224 & -0.0281 & 1.0000 & & & & & \\
\hline Woman's role & -0.0269 & -0.0386 & 0.0528 & 1.0000 & & & & \\
\hline Distance $w^{a}$ & 0.0920 & -0.0381 & -0.0309 & -0.0288 & 1.0000 & & & \\
\hline Distance HC & 0.0347 & -0.0155 & -0.0049 & 0.0522 & 0.0518 & 1.0000 & & \\
\hline Income & 0.0052 & -0.0027 & 0.0239 & -0.0055 & -0.0203 & -0.0932 & 1.0000 & \\
\hline
\end{tabular}

a Distance to the nearest health center

b Distance to the nearest water sources

It implies that as the educational level of the household head increases, the level of understanding about climate change adaptation increases. In LTSB, a significant number of household heads are illiterate and highly vulnerable to climate change hazards. Similarly, households who are rich in wealth relatively cop up climate change more than the poor. They stated in the focus group discussion also that during the loss of crop and livestock might lead to food problems for the coming season more by the poor than the rich households. Agricultural extension services played a significant role for climate change adaptation. Access to extension services also increases the likelihood of adaptation to climate change impacts. This suggests that extension services help farmers to take climate change and weather patterns into account and help advise them on how to tackle climatic variability and change. The likelihoods of agricultural extension services and off-farm employment is also found to be significant in adapting climate change in LTSB more by those who engaged in than the non-users.

The likelihood of climate change perception of households for the variables of agro-ecology, marital status, farm size, climate change information access and income from crop sale found to be statistically significant at the $1 \%$ level of significance. Farmers' perception of having large farm size increases the probability of taking up adaptation in response to changes in the climate. This implies that farmers who have large farm size have high probability to diversify crops for better adaptation options.

The likelihoods of getting resistant variety increase due to the larger farm size. The results also show important regional variation in the case of agro-ecology. Farmers in the LSB region are more likely to adapt compared with farmers in the LSB. Indeed, in both cases, the population is largely rural and the main rural economic activity is agriculture. The accessibility of small scale irrigation and moisture enabled the LSB households for better resistance to climate change than the USB.

This section presents the empirical results of the Multinomial Logistic (MNL) regression adaptation model. The MNL, as specified above with nine adaptation options, (use of climate change resilient variety, forage stock, crop diversity, crop intensity, change planting 
Table 5 Results of the Heckman probit model of adaptations behavior

\begin{tabular}{|c|c|c|c|c|c|c|}
\hline \multirow[b]{2}{*}{ Adaptation } & \multirow[t]{2}{*}{ Coef. } & \multirow[t]{2}{*}{ Std. err. } & \multirow[t]{2}{*}{$\mathbf{z}$} & \multirow[t]{2}{*}{$P>|z|$} & \multicolumn{2}{|c|}{$95 \%$ Conf. interval } \\
\hline & & & & & & \\
\hline Age & -.1415596 & .2830265 & -0.50 & 0.617 & -.6962814 & .4131623 \\
\hline Sex & -.5884895 & .1532126 & -3.84 & $0.000^{* * *}$ & -.8887807 & -.2881984 \\
\hline Agro-ecology & .0429117 & .1341781 & 0.32 & 0.749 & -.2200726 & .305896 \\
\hline Education & -.2363284 & .1214751 & -1.95 & $0.052^{*}$ & -.4744152 & .0017584 \\
\hline Marital status & .0646762 & .2565958 & 0.25 & 0.801 & -.4382422 & .5675947 \\
\hline $\mathrm{HH}$ size & .0277019 & .0289063 & 0.96 & 0.338 & -.0289534 & .0843571 \\
\hline Wealth status & -.2591666 & .1347339 & -1.92 & $0.054^{*}$ & -.5232403 & .004907 \\
\hline Farm size & -.1288587 & .1028949 & -1.25 & 0.210 & -.330529 & .0728115 \\
\hline Extension & -.23966 & .1275975 & -1.88 & $0.060^{*}$ & -.4897465 & .0104265 \\
\hline Off farm & -.0536978 & .1130677 & -0.47 & 0.635 & -.2753064 & .1679108 \\
\hline Information & .0745562 & .1884574 & 0.40 & 0.692 & -.2948136 & .4439259 \\
\hline Woman's role & .0308976 & .1271461 & 0.24 & 0.808 & -.2183042 & .2800994 \\
\hline Distance w & -.036144 & .0332134 & -1.09 & 0.276 & -.1012411 & .0289531 \\
\hline Distance HC & .0357303 & .0152648 & 2.34 & $0.019^{* *}$ & .0058119 & .0656487 \\
\hline Income & $-5.94 e-06$ & $6.08 \mathrm{e}-06$ & -0.98 & 0.329 & -.0000179 & $5.99 \mathrm{e}-06$ \\
\hline cons & -.0182561 & .4436095 & -0.04 & 0.967 & -.8877149 & .8512026 \\
\hline \multicolumn{7}{|l|}{ Perception } \\
\hline Age & 7.370322 & & & & & \\
\hline Sex & .238111 & .2408228 & 0.99 & 0.323 & -.2338929 & .710115 \\
\hline Agro-ecology & -.6300321 & .2116227 & -2.98 & $0.003^{* * *}$ & -1.044805 & -.2152592 \\
\hline Education & -.1458639 & .1778687 & -0.82 & 0.412 & -.4944802 & .2027524 \\
\hline Marital status & .9278242 & .2928511 & 3.17 & $0.002^{* * *}$ & .3538466 & 1.501802 \\
\hline HH size & -.0731338 & .0452779 & -1.62 & 0.106 & -.1618769 & .0156094 \\
\hline Wealth status & .071489 & .226968 & 0.31 & 0.753 & -.3733602 & .5163381 \\
\hline Farm size & .7208861 & .1924143 & 3.75 & $0.000^{* * *}$ & .343761 & 1.098011 \\
\hline Extension & -.0553093 & 1918306 & -0.29 & 0.773 & -.4312905 & .3206718 \\
\hline Off farm & .2175154 & .1684565 & 1.29 & 0.197 & -.1126532 & .547684 \\
\hline Information & .8733192 & .212489 & 4.11 & $0.000^{* * *}$ & .4568485 & 1.28979 \\
\hline Women role & .2353382 & .1774769 & 1.33 & 0.185 & -.1125102 & .5831866 \\
\hline Distance to w & .0664353 & .0568058 & 1.17 & 0.242 & -.0449021 & .1777726 \\
\hline Distance to $\mathrm{HC}$ & .0028078 & .0230233 & 0.12 & 0.903 & -.042317 & .0479327 \\
\hline Income & -.00002 & $6.51 e-06$ & -3.07 & $0.002^{* * *}$ & -.0000327 & $-7.23 e-06$ \\
\hline _cons & -.4984487 & .4962166 & -1.00 & 0.315 & -1.471015 & .4741179 \\
\hline /athrho & 1.338615 & 1.490205 & 0.90 & 0.369 & -1.582133 & 4.259364 \\
\hline Rho & .8713392 & .3587937 & & & -.9189344 & .9996007 \\
\hline
\end{tabular}

LR test of indep. eqns. $($ rho $=0): X^{2}(1)=1.25$ Prob $>X^{2}=0.2640$. Probit model with sample selection, number of observation $=599$, Wald $x^{2}(15)=46.99$, Prob $>x^{2}=0.0000$. Dummy variable takes the value of 1 and 0 otherwise

* Significant at $10 \%,{ }^{* *}$ Significant at $5 \%$ and ${ }^{* * *}$ Significant at $1 \%$

date, irrigation, water harvesting, soil and water conservation, fertilizer use and others) failed to produce satisfactory results in terms of the significance level of the parameter estimates and also in terms of the validity of the independence of irrelevant alternatives (IIA) assumption. The model was thus restructured by grouping five closely related choices together in the same category. The replacement of soil and water conservation works, water harvesting schemes, fertilizer application and forage stock to land resources management and cropping intensity along with crop diversification were rearranged and given as follows:

- Use of climate change resilient variety (both crop and livestock)

- Crop diversification

- Change planting date

- Irrigation

- Others

- No adaptation 
The MNL adaptation model with these restructuring choices was run and tested for the IIA assumption using the Hausman specification test statistics. Thus, the application of the MNL specification to the data set for modeling climate change adaptation behavior of farmers has been justified. Appendices XIII and XIV present the estimated coefficients and the marginal effects, respectively. The likelihood ratio statistics as indicated by $x^{2}=102.07$ were found to be highly significant at $1 \%$ level of significance, suggesting strong explanatory power of the model. It is important to note that the estimated coefficients should be compared with the base category of land resource management any of the adaptation choices.

Perception of climate change and adaptation with respect to a unit change in an independent variable. Additionally, results show that most of the explanatory variables under their marginal values are statistically significant at $10 \%$ level of significance and signs on most of the variables are as expected (Table 6). Agro-ecology and educational level of the household heads of the LTSB with the base category of the land resources management was significant at the $1 \%$ level of significance by using climate change impact resilient varieties.

In the climate change resilient category, the household's response of whether they have used highly resistant livestock and crop varieties to adapt climate change during data collection was considered. On the other hand, means of transport to the nearest market is found to be statistically significant at with the base category under the crop diversification options at the $1 \%$ level of significance.

The coefficient on agro-ecology is statistically significant and positively correlated with the probability of choosing irrigation as an adaptation measure. Indeed, the nature of weather and climate in both USB and LSB households is more likely to adapt because of the high vulnerability to the frequent occurrence of climate change hazards. Farmers argued in the FGD also that adaptation strategies have a number of obstacles to fully implement since most of the rural households are depending on subsistence agricultural practice in a fragile environment.

\section{Conclusion}

The Heckman probit and multinomial logistic regression models were applied to examine the determinants of adaptation to climate change impacts. Results revealed that age, educational level, wealth, status, agricultural extension services, and distance to the nearest health center are found to be statistically significant factors for climate change adaptation in LTSB. The farmers' perception to climate change are also found statistically significant for the factors of agro-ecology type, marital status, farm size, climate change information access and the level of income generations. Moreover, agro-ecology and educational level of the household heads also significant by using climate change impact resilient varieties; On the other hand, means of transport to the nearest market was significant at with the base category under the crop

Table 6 Marginal effects after multinomial logistic regression adaptation model

\begin{tabular}{|c|c|c|c|c|c|c|}
\hline $\begin{array}{l}\text { Dummy }(1=\text { value, } \\
0 \text { otherwise) }\end{array}$ & $\mathrm{CCl}$ resilient varity & Crop diversification & $\begin{array}{l}\text { Change planting } \\
\text { data }\end{array}$ & Irrigation & Others & No adaptation \\
\hline Age & $-.0952168(0.228)$ & $-0.0496239(0.502)$ & $0.090527(0.379)$ & $-.0693226(0.328)$ & $0.07981(0.993)$ & $-.01115(0.647$ \\
\hline ex & $.0526134(0.290)$ & $0.003926(0.926)$ & $0.0563597(0.253)$ & $-.0687459(0.103)$ & $0.01735(0.994)$ & $-.001715(0.916)$ \\
\hline gro-ecology & $.1295817(0.009)^{* * *}$ & $-0.0457134(0.301)$ & $-0.014458(0.776)$ & $-.1987125(0.001)^{* * *}$ & $0.14539(0.994)$ & $-.0297748(0.115)$ \\
\hline ducation & $.0779969(0.047)^{* *}$ & $0.0209818(0.546)$ & $-0.022705(0.537)$ & $-.0254586(0.483)$ & $0.00785(0.994)$ & $.0120754(0.438)$ \\
\hline Marital status & $-.0359775(0.613)$ & $0.011298(0.854)$ & $0.0066574(0.92)$ & $-.0545598(0.522)$ & $0.04508(0.994)$ & $.0018236(0.944)$ \\
\hline HH size & $-.0035823(0.742)$ & $0.0036775(0.705)$ & $-0.004241(0.697)$ & $.0125151(0.222)$ & 0.0277 (0.994) & $.0315775(0.743)$ \\
\hline Vealth & $.0717447(0.838)$ & $0.0548825(0.16)$ & $0.0643558(0.152)$ & $-.0016338(0.969)$ & $0.02407(0.994)$ & $.0315775(0.111)$ \\
\hline ze & $0.005622(0.863)$ & $-0.0370213(0.22)$ & $18792(0.545)$ & $.0241122(0.396)$ & 0.0009 (0.994) & $548(0.269)$ \\
\hline Agricultural extension & $0.021709(0.596)$ & $0.0183039(0.622)$ & $0.0496881(0.212)$ & $-.0808347(0.091)$ & $0.05626(0.994)$ & $.0084358(0.590)$ \\
\hline Off farm E & $-0.01155(0.75)$ & $-0.0091922(0.781)$ & $0.0171024(0.638)$ & $-.0097109(0.786)$ & 0.0076 (0.994) & $.0033078(0.815)$ \\
\hline information access & $-0.08595(0.255)$ & $0.0443577(0.5)$ & $0.0652358(0.382)$ & $.0397348(0.595)$ & $0.30529(0.988)$ & $.0058787(0.759)$ \\
\hline Transport to the market & t $0.003486(0.955)$ & $-0.1723306(0.000)^{* * *}$ & $0.0724948(0.254)$ & $-.1175472(0.002)^{* * *}$ & $0.04142(0.994)$ & $.0016269(0.930)$ \\
\hline Women participation & $0.031176(0.436)$ & $0.0210627(0.567)$ & $0.0335759(0.429)$ & $.0124976(0.760)$ & $0.05569(0.994)$ & $-.0165474(0.363)$ \\
\hline Distance to water & $-0.01462(0.169)$ & $0.0050145(0.585)$ & $0.0104048(0.298)$ & $.0021788(0.820)$ & $0.00464(0.994)$ & $.0047723(0.135)$ \\
\hline $\begin{array}{l}\text { Distance to health } \\
\text { center }\end{array}$ & $-0.00398(0.413)$ & $-0.0000992(0.982)$ & $0.0040938(0.391)$ & $-.0018473(0.696)$ & $0.00514(0.994)$ & $.0011576(0.535)$ \\
\hline Income from off-farm & $1.1906(0.531)$ & $-2.38 \mathrm{E}-06(0.307)$ & $1.4506(0.429)$ & $-2.2006(0.343)$ & $0.00000(0.994)$ & $6.2607(0.211)$ \\
\hline Income from crop sale & $1.1406(0.907)$ & $0.0000156(0.062)^{*}$ & $-2.78 \mathrm{E}-06(0.784)$ & $-5.2007(0.958)$ & $0.00001(0.994)$ & $1.5506(0.674$ \\
\hline
\end{tabular}

The calculated marginal effects measure the expected changes in the probability of both 
diversification. Most of the adaptation plans, policies, and strategies have tried to be implemented, but most of the respondent's evaluations indicated that inefficient, which means did not meet the demand up to the anticipated level.

In general based on the results of this research work, there should be:

- Designing and implementing a well-organized climate awareness mechanism based on dynamic empirical information at different spatial scales;

- Designing and implementing interventions that address capacity, technology and information needs of households experiencing different climatic hazards;

- Promotion of "saving as a culture" among rural households and strengthening service provision capacity of rural financial institutions;

- Research based and farmer friendly technology intervention in irrigation, water harvesting, and moisture management practices for drought mitigation;

- Massive restoration of degraded lands and more importantly through indigenous flora and in view of community friendly economic and ecological benefit mechanisms;

- Rural agro-processing, value chain development, and risk financing schemes;

- Organization, capacity building, and access to inputs for landless and unemployed segments of rural households;

\begin{abstract}
Authors' contributions
SA has made substantial contributions in conception design, acquisition of data, and interpretation of results and leading the overall activities of the research; He has given also the final approval of the version to be published. BG and GF have been involved in data collection, entry, coding, and analysis. YA contributed in writing, drafting the manuscript, revising it critically for important intellectual content. All authors read and approved the final manuscript.
\end{abstract}

\section{Author details}

${ }^{1}$ Department of Natural Resources Management, College of Agriculture and Environmental Sciences, Bahir Dar University, Bahir Dar, Ethiopia. ${ }^{2}$ Rural Development and Agricultural Extension, College of Agriculture and Environmental Sciences, Bahir Dar University, Bahir Dar, Ethiopia.

\section{Acknowledgements}

This study would never be completed without the contribution of many people to whom we would like to express our gratitude. The administrative kebeles development agents, district agricultural officials, local guiders, committee leaders and respondent households in each of the sampling kebeles were indispensable for the successful completion of the field work. We would like also to acknowledge people who contributed their knowledge and time in data collection and entry processes.

\section{Competing interests}

The authors declare that they have no competing interests.

Received: 11 December 2015 Accepted: 3 February 2016

Published online: 16 February 2016

\section{References}

Cochran WG (1977). Sampling techniques (3rd edn) New York, John Wiley and Sons. 2010. Country report on, Managing risk, reducing vulnerability and enhancing of agricultural productivity under changing climate in the greater horn of Africa. Retrieved August, 2013, from climate change profile of Ethiopia

CSA (Central Statistical Agency) (2007). Central Statistical Agency Population and Housing Census of Ethiopia, Addis Ababa. Retrieved August, 2013, from CSA database

Daberkow SG, McBride WD (2003) Farm and operator characteristics affecting the awareness and adoption of precision of agriculture technologies in the US. Precision Agric 4:163-177

Elasha BO, Medany M, Niang-Diop I, Nyong T, Tabo R, Vogel C (2006). Background paper on impacts, vulnerability and adaptation to climate change in Africa for the African Workshop on Adaptation Implementation of Decision 1/CP.10 of the UNFCCC Convention, Accra, 21-23 September, 2006. $54 \mathrm{pp}$

Glwadys AG (2009) Understanding Farmers'Perceptions and Adaptations to Climate Change and Variability, the Case of the Limpopo Basin, South Africa. International Food policy Research Institute, IFPRI discussion paper 00849, Retrieved April, 2013, from website http://www.ifpri.org

IPCC (2001) Climate Change 2001: Impacts, Adaptation and Vulnerability. Cambridge University Press, Cambridge

Robinson S, Willenbockel D, Strzepek K (2012) A dynamic general equilibrium analysis of adaptation to climate change in Ethiopia. Rev Dev Econ 16(3):489-502

Shiferaw B, Holden S (1998) Resource degradation and adoption of land conservation technologies in the Ethiopian Highlands: a case study in Andit Tid, North Shewa. Agric Econ 18:233-247

Teklewold H, Dadi L, Yami A, Dana N (2006) Determinants of adoption of poultry technology: A double hurdle approach. Livestock Research for Rural Development 18(3). Retrieved April, 2013 from http://www.lrrd.org/ Irrd18/3/tekl18040.htm

Tizale CY (2007) The dynamics of soil degradation and incentives for optimal management in the Central Highlands of Ethiopia. PhD thesis, Faculty of Natural and Agricultural Sciences, Retrieved October 23, 2013, from the University of Pretoria digital theses 